\title{
Pengembangan awetan invertebrata disertai panduan praktikum sebagai sumber belajar
}

\author{
Nabela Fikriyya ${ }^{1 *}$, Sulistiyawati ${ }^{2}$ \\ Pendidikan Biologi, Fakultas Sains dan Teknologi, UIN Sunan Kalijaga Yogyakarta \\ Jl. Laksda Adisucipto, Papringan, Caturtunggal, Kec.Depok Kab. Sleman, Yogyakarta 55281 \\ ${ }_{1}^{1}$ nabela.fikriyya@ui.ac.id*; tiyawati83@gmail.com \\ *korespondensi penulis
}

\begin{abstract}
Abstrak
Ketersediaan sarana dan prasarana yang mendukung kegiatan praktikum dapat mendukung proses pembelajaran berjalan secara efektif dan efeisen. Salah satunya adalah ketersediaan awetan dan panduan praktikum yang mana keduanya masih menjadi kendala di beberapa sekolah. Penelitian ini bertujuan untuk menghasilkan awetan invertebrata dan panduan praktikum sebagai sumber belajar serta mengetahui kualitas produk yang dihasilkan. Penelitian pertama berupa pengambilan sampel awetan invertebrata di Pantai Krakal, Gunungkidul, Yogyakarta dan menghasilkan 50 jenis dari 7 kelas invertebrata. Hasil penelitian dikembangkan menjadi awetan basah dan awetan kering. Penelitian ini juga mengembangkan panduan praktikum yang terdiri dari dua bagian yakni panduan praktikum untuk siswa dan untuk guru. Produk dinilai dan divalidasi oleh 1 ahli materi, 1 ahli media dan 5 peer reviewer. Instrumen penilaian produk dan respon siswa berupa lembar angket yang terdiri aspek materi, aspek penyajian panduan praktikum, aspek penyajian awetan, aspek penilaian autentik dan aspek bahasa. Uji coba terbatas dilakukan oleh 2 guru biologi dan 10 siswa MAN 2 Sleman dan MAN 4 Bantul. Kualitas awetan dan panduan praktikum menurut para ahli, peer reviewer, guru dan siswa masing-masing mendapatkan persentase berturut-turut $89,18 \%, 88,53 \%, 88,75 \%$ dan $84,63 \%$. Kategori kualitas produk secara keseluruhan adalah sangat baik (SB) dengan persentase sebesar $88,17 \%$.
\end{abstract}

Kata kunci: awetan invertebrata, panduan praktikum, sumber belajar

\begin{abstract}
The availability of facilities and infrastructure that supports practicum activities can support the learning process to effectively and efficiently. One of is the availability of preserved and practicum guidelines, which both are still an obstacle in some schools. The purpose of this study is to produce invertebrate preservation and invertebrate practicum guidelines as a source of learning and to fdetermine its quality. The first study was invertebrate preservation at Krakal Beach, Gunungkidul, Yogyakarta and produced 50 species of 7 classes of invertebrates. The results of the study were developed into wet preserved and dry preserved. This study also developed a practicum guideline consisting of two parts namely a practicum guideline for students and for teachers. Products are assessed and validated by 1 material expert, 1 media expert and 5 peer reviewers. Instrument for evaluating products and student responses in the form of questionnaire sheets consisting of aspects of the material, aspects of the presentation of practicum guidelines, aspects of preservation, aspects of authentic assessment and aspects of language. Limited trials were conducted by 2 biology teachers and 10 students from MAN 2 Sleman and MAN 4 Bantul. The quality of preservation and practicum guidelines according to experts, peer reviewers, teachers and students each get consecutive percentages of $89.18 \%, 88.53 \%, 88.75 \%$ and
\end{abstract}


$84.63 \%$. The overall product quality category was very good (VG) with a percentage of $88.17 \%$.

Keywords: invertebrates preservation, practicum guide, learning resources

\section{PENDAHULUAN}

Pembelajaran biologi tidak hanya cukup dengan menghafal teori, tetapi siswa juga harus diberikan pengalaman dan praktik untuk mengembangkan potensi berpikir mandiri dan ilmiah. Untuk mencapai hal tersebut guru harus dapat memfasilitasi kegiatan belajar agar dapat terlaksana sesuai dengan tujuan, salah satunya dengan melaksanakan kegiatan praktikum (Setiawan, 2008 dalam Imtihana et al., 2014). Kegiatan praktikum merupakan salah satu cara untuk meningkatkan soft skill siswa dalam pengamatan dan penggunaan peralatan laboratorium (Khamidah dan Aprilia, 2014). Selain itu, kegiatan praktikum juga melibatkan pengalaman nyata dengan menggabungkan aktivitas fisik dan mental sehingga memperoleh konsep secara mandiri dan dapat meningkatkan ingatan sampai $90 \%$ dari apa yang dilakukan dan dikatakan (Komalasari, 2011 dan Adhayul et al., 2014)

Keberhasilan kegiatan praktikum dikelas adalah salah satu acuan keberhasilan pembelajaran biologi. Tanpa adanya kegiatan praktikum yang optimal dapat mengurangi keberhasilan pembelajaran biologi (Setiawan, 2008 dalam Imtihana et al., 2004 dan Arifin, 2005 dalam Hedianti, 2015). Pentingnya kegiatan praktikum bagi siswa salah satunya untuk memfasilitasi Kompetensi Dasar (KD) 3.8 dan 4.8 yang berisi tentang penerapan prinsip klasifikasi hewan kedalam filum yang didasarkan oleh pengamatan dan perannya serta menyajikan data dalam bentuk laporan tertulis. Namun, kegiatan praktikum dalam pelaksanaannya belum maksimal karena memiliki beberapa kendala seperti: belum tersedianya buku panduan praktikum, bahan dan alat, serta guru belum memiliki panduan penilaian keterampilan proses dan sikap ilmiah (Tuysuz, 2010).

Salah satu upaya untuk mengoptimalkan materi invertebrata adalah dengan menyediakan sarana dan prasarana yang dapat mendukung kegiatan praktikum berupa sumber belajar yang meliputi awetan dan panduan praktikum. Ketersediaan sumber belajar yang sesuai dengan kebutuhan merupakan salah satu faktor penting untuk mencapai keberhasilan pembelajaran (Nikmah dan Binadja, 2015). Media awetan merupakan sumber belajar yang sesuai untuk diterapkan pada materi invertebrata dimana siswa dapat mendiskripsikan ciri-ciri umum dari setiap perwakilan hewan invertebrata secara detail (Mega dan Soeparjitno, 2017). Media awetan akan memberikan pengalaman belajar yang konseptual dan teoretis karena disajikan secara detail dan riil (Dikmenli, 2009 dalam Sobirin et al., 2013). Hal tersebut juga ditunjang 
pula dengan panduan praktikum yang membantu siswa untuk mempelajari materi agar lebih terarah, memudahkan dan memberikan informasi dalam melakukan kegiatan praktikum (Arifah et al., 2014).

Berdasarkan permasalahan tersebut tujuan penelitian ini adalah mengembangkan awetan dan panduan praktikum yang layak digunakan sehingga membantu siswa dalam mempelajari materi invertberata.

\section{METODE}

\section{Pengambilan data dan gambar invetebrata}

Penelitian dilakukan pada bulan Maret-Mei 2017 di zona intertidal Pantai Krakal Gunungkidul pada saat pantai mencapai surut maksimal. Alat yang digunakan yaitu plot berukuran $1 \times 1 \mathrm{~m}^{2}$, meteran (met line), pinset, glove, nampan, kertas label, botol, alat tulis dan kamera. Bahan yang digunakan adalah buku identifikasi, akuades, formalin 4\%, dan alkohol 70\% (Rusyana, 2013). Teknik pengambilan sampel menggunakan random sampling dengan metode transek kuadrat dengan ukuran $1 \times 1 \mathrm{~m}^{2}$ dan membagi daerah penelitian menjadi 30 plot dengan jarak antar plot \pm 10 meter. Setiap individu yang ditemukan kemudian dihitung pada masing-masing spesies, didokumentasikan dan diambil sampel setiap spesies. Identifikasi menggunakan buku Laboratory and Field Text in Invertebrata Zoology (Light, 1941), website marinespecies.org, dan jurnal terkait invertebrata laut. Data hasil identifikasi spesies dianalisis secara deskriptif kualitatif.

\section{Pengawetan invertebrata laut}

Pengawetan terdiri dari dua cara yaitu pengawetan basah dan pengawetan kering. Pengawetan basah dilakukan untuk hewan tidak bercangkang yang relatif besar, kelompok crustacea atau kelompok invertebrata lainnya (Suyitno, 2004). Langkah pertama dalam pengawetan basah adalah mematikan objek dengan merendamnya di dalam air tawar, fiksasi dan pengawetan. Fiksasi bertujuan untuk menstabilkan protein jaringan dengan menggunakan formalin $4 \%$ yang berfungsi sebagai desinfektan yang efektif melawan bakteri, jamur, atau virus sehingga dapat mengurangi aktivitas mikroorganisme (Cahyadi, 2009 dan Suhardi, 1988). Tahap pengawetan menggunakan alkohol $70 \%$ yang berfungsi sebagai antimikrobial dan pelarut lipid untuk mencegah pembusukan (Pelczar dan Chan, 2013).

Pengawetan kering dilakukan dengan mengeringkan obyek biologi hingga kadar air yang sangat rendah, sehingga organisme perusak tidak bekerja. Untuk cangkang dan kerang, pengawetan dilakukan dengan membuang bagian tubuh yang lunak dengan menggunakan 
pinset. Kemudian dibersihkan, dicuci dan dikeringkan. selanjutnya dilakukan proses penataan, dengan mempelkan cangkang pada kertas menggunakan lem tembak. Tahap terakhir dari kedua proses pengawetan adalah pemberian label pada objek yang berisi informasi tentang nama spesimen, lokasi pengambilan, tanggal pengambilan, dan determinator (Rusyana, 2013).

\section{Pengembangan Panduan Praktikum}

Pada tahap perancangan, peneliti membuat rancangan produk atau prototype yang meliputi penyusunan materi atau isi sistematika penulisan dan perancangan alat evaluasi melalui Microsoft word 2016. Aplikasi pengembangan yang digunakan dalam pengembangan panduan praktikum adalah Adobe indesign CS5.5 dan CorelDRAW X7.

\section{Uji Coba Produk}

Subyek uji coba dalam penelitian ini adalah 1 ahli materi, 1 ahli media dan 5 peer reviewer sebagai tahap validasi produk. Sedangkan reviewer tahap uji coba terbatas terdiri dari 2 guru biologi dan 20 siswa. Penelitian ini dilakukan pada bulan Juli-Agustus 2017. Uji coba dilakukan di MAN 2 Sleman dan MAN 4 Bantul. Instrumen penilaian berupa lembar angket jenis skala likert dengan bentuk checklist yang terdiri aspek materi, aspek penyajian panduan praktikum, aspek penyajian awetan, aspek penilaian autentik dan aspek bahasa.

\section{HASIL DAN PEMBAHASAN}

\section{Keanekaragaman Invertebrata Laut di Zona Intertidal Pantai Krakal}

Penelitian dilakukan di Pantai Krakal pada zona intertidal yang merupakan daerah peralihan dari kondisi lautan ke kondisi daratan dan memiliki keanekaragaman hayati yang tinggi (Dahuri, 2003). Berdasarkan penelitian dilakukan, indeks keanekaragaman (H') jenis invertebrata laut adalah 1,505 termasuk dalam kategori "sedang". Hal ini menunjukkan bahwa kondisi lingkungan di Pantai Krakal relatif stabil untuk kehidupan berbagai macam Invertebrata laut (Yanu, 2010). Pantai Krakal sendiri termasuk jenis pantai berbatu yang dicirikan adanya belahan batu cadas dan tersusun dari bahan yang keras sehingga permukaan batuan tersebut dapat melindungi organisme dari panas dan predator serta substrat yang baik untuk pertumbuhan dan perkembangan berbagai jenis tumbuhan dan hewan (Dahuri, 2003 dan Ramli, 1989 dalam Trisna et al., 2016).

Pada penelitian ini ditemukan sebanyak 50 spesies invertebrata laut yang tergolong dalam 7 filum meliputi: Mollusca 22 spesies, Cnidaria 8 spesies, Echinodermata 7 spesies, Arthropoda 6 spesies, Porifera 4 spesies, Annelida 2 spesies dan Platyhelminthes 1 spesies. 
Individu yang paling banyak ditemukan adalah dari filum Mollusca yakni sebanyak 655 individu dari 1303 jumlah keseluruhan individu. Hal tersebut sesuai dengan yang dikemukakan oleh Dahuri (2003) bahwa filum Mollusca merupakan kelompok biota perairan laut Indonesia yang memiliki tingkat keragaman paling tinggi dan banyak hidup di daerah ekosistem karang dan padang lamun.

Filum Mollusca yag ditemukan terbagi menjadi 3 kelas yakni gastropoda, bivalvia dan polyplacopora. Kelas gastropoda ditemukan paling banyak yakni, 18 spesies. Barnes (1987) dalam Dibyowati (2009) menyatakan bahwa gastropoda merupakan kelas dari filum Mollusca yang paling sukses karena menguasai berbagai habitat yang bervariasi. Spesies yang paling banyak ditemukan dari kelas gastropoda adalah Cypraea annulus sebanyak 70 individu. Hal ini disebabkan spesies ini lebih menyukai daerah yang bersubstrat keras, pemakan alga, spons atau hewan kecil yang tumbuh di atas batuan (FAO, 1998 dalam Trisna et al., 2016).

\section{Hasil Pengujian Produk}

Produk yang dikembangkan yakni awetan invertebrata laut disertai panduan praktikum. Tahap uji coba produk diawali dengan proses validasi oleh para ahli yang bertujuan untuk mengetahui kekurangan dan kelemahan produk, sehingga perbaikan dapat dilakukan untuk menghasilkan produk yang ideal (Istianah et al., 2012). Aspek materi menurut ahli materi dinyatakan sangat baik dengan persentase sebesar 94,44\% (Lihat Gambar 1.), karena dalam penyusunannya disesuaikan dengan materi tingkat SMA dan KD yang akan dicapai serta bersumber dari buku universitas dan jurnal-jurnal penelitian terpublikasi yang akurat (Prastowo, 2011 dan Cresswell, 2012 dalam Khusnul, 2017). Desain materi disesuaikan dengan teori perkembangan piaget dimana siswa SMA termasuk dalam tahap operasional formal (11/12-18thn) yang dicirikan dengan anak sudah dapat berpikir abstrak dan logis yang mana telah tersedia didalam panduan praktikum berupa hipotesis, pengamatan, tugas mandiri dan menarik kesimpulan (Komalasari, 2011). Pengetahuan tambahan tentang materi invertebrata juga diberikan melalui kolom "tahukah kamu” yang disajikan pada setiap akhir kegiatan praktikum. 


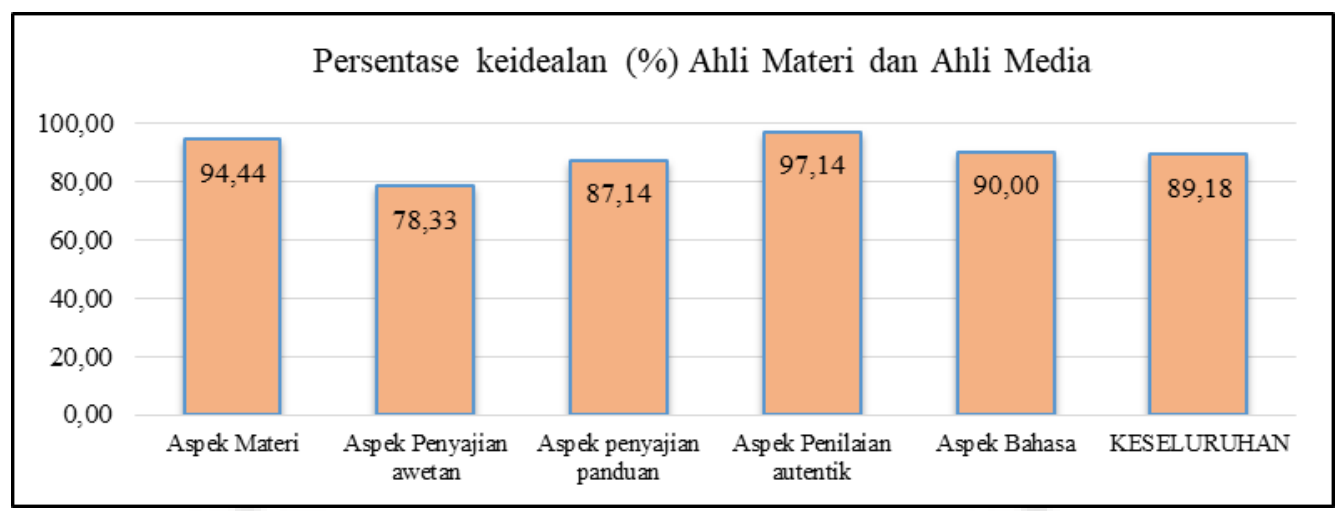

Gambar 1. Diagram persentase penilaian ahli materi dan ahli media

Panduan praktikum yang dikembangkan terdiri dari dua macam yakni panduan praktikum pegangan guru dan pegangan siswa. Bagian utama panduan praktikum pegangan siswa terdiri 5 kegiatan praktikum dan 1 kegiatan praktikum tambahan berupa cara pengoleksian dan pengawetan invertebrata serta dilengkapi pula dengan penilaian autentik berupa penilaian sikap yang terdiri dari penilaian diri dan penilaian antar teman. Andrade \& Valtcheva (2009) dan Oscaron dalam Fuji (2014) menjelaskan bahwa dengan penggunaan penilaian diri, siswa dapat melakukan refleksi terhadap kualitas pekerjaan mereka, melakukan perbaikan terhadap pembelajaran dan meningkatkan kepekaan siswa dalam belajar. Selanjutnya untuk panduan praktikum pegangan guru berisi kunci jawaban dari soal dan tugas yang terdapat pada buku siswa dan deskripsi spesies pada panduan identifikasi spesies serta panduan penilaian sikap dan penilaian laporan.

Aspek penyajian awetan mendapatkan penilaian terendah dengan kategori penilaian "Baik" dengan persentase sebesar 78,33\% (Lihat Gambar 1.) sehingga peneliti melakukan perbaikan penyajian media awetan sesuai saran. Penyajian awetan yang menarik termasuk salah satu aspek yang dapat menumbuhkan minat dan motivasi siswa dalam belajar. Hal ini sesuai dengan Prastowo (2012) dalam Adhayul et al., (2014) yang menyatakan bahwa sumber belajar harus memenuhi beberapa persyaratan antara lain: praktis, mudah diperoleh, fleksibel, sesuai dengan tujuan, serta dapat memotivasi siswa.

Aspek penyajian panduan praktikum oleh peer reviewer dan 2 guru biologi mendapatkan nilai tertinggi yakni sebesar 92,73\% dan 91,43\% (Lihat Gambar 2. Dan 3.) dengan kategori "Sangat Baik", karena panduan praktikum yang dikembangkan memiliki tampilan yang menarik dan dicetak dengan full colour. Depdiknas (2004) dalam Adhayul et al., (2014) menyatakan bahwa dalam penyusunan bahan ajar cetak sangat penting memperhatikan stimulan/kemenarikan dan kemudahan untuk dibaca. Desain layout dan cover setiap kegiatan 
menggunakan gambar perwakilan spesies yang akan dipelajari sehingga siswa terstimulasi terhadap apa yang akan dipelajari. Hal ini sesuai dengan pernyataan Komalasari (2011) bahwa penggunaan gambar atau foto dapat memberikan gambaran nyata sehingga memberikan makna pembelajaran yang lebih hidup dan tepat serta merangsang kemampuan berpikir siswa.

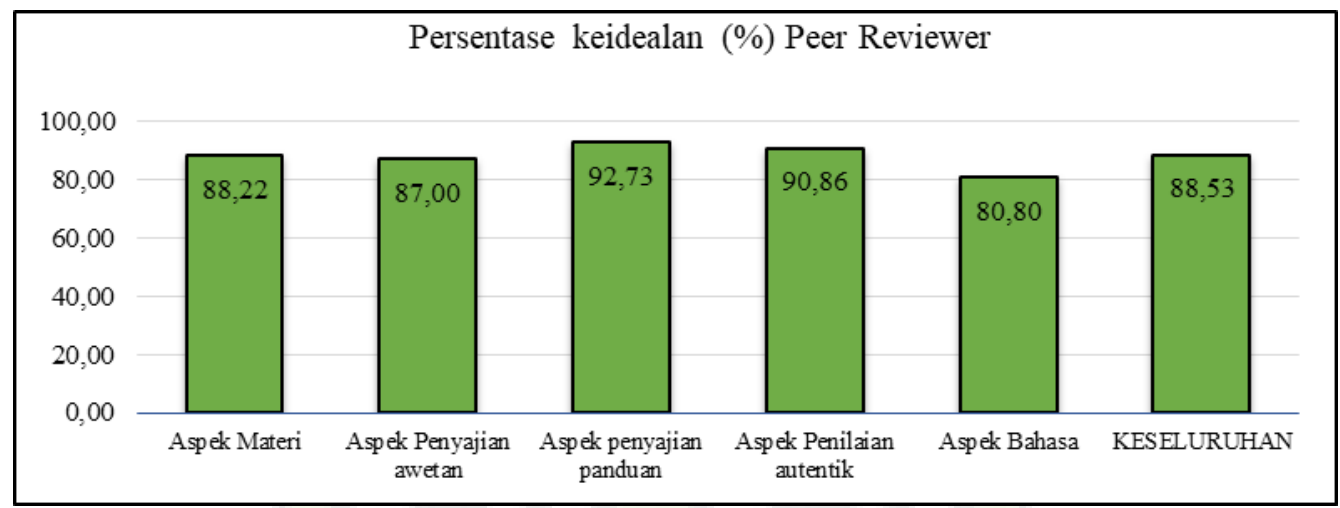

Gambar 2. Diagram persentase penilaian peer reviewer

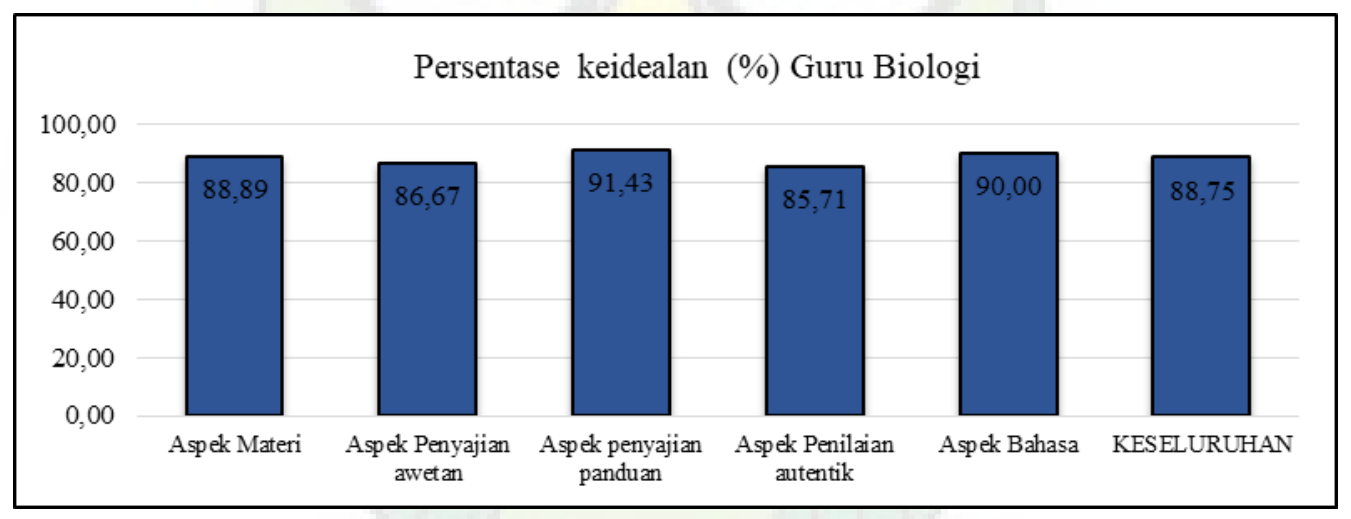

Gambar 3. Diagram persentase penilaian guru biologi

Aspek bahasa oleh peer reviewer mendapatkan nilai terendah yakni sebesar $80,80 \%$ (Lihat Gambar 2.) dengan kategori "baik", sehingga peneliti melakukan perbaikan sesuai saran. Menurut Diknas (2004) dalam Prastowo (2011) salah satu unsur yang harus diperhatikan dalam penyusunan bahan ajar cetak adalah kemudahan dalam membaca yang nampak pada penggunaan font dan teks yang terstruktur. Selain itu, penggunaan bahasa yang sesuai dengan tingkat perkembangan anak akan memotivasi untuk belajar keras dan belajar cerdas. 


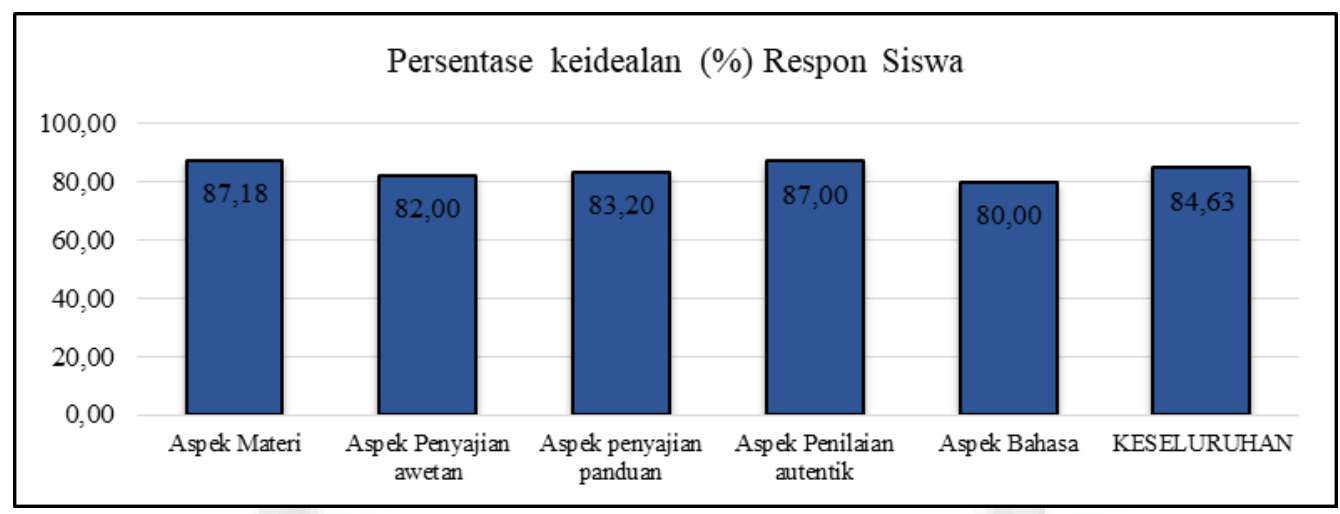

Gambar 4. Diagram persentase penilaian respon siswa

Berdasarkan uji coba terbatas, mayoritas siswa memberikan respon positif terhadap awetan dan panduan praktikum. Hasil analisis respon siswa terhadap awetan dan panduan praktikum memperoleh nilai keseluruhan sebesar 84,63\% dengan nilai tertinggi pada aspek materi sebesar 87,18\% dengan kategori "sangat baik" (Lihat Gambar 4), karena siswa diberikan pengalaman nyata berupa kegiatan praktikum menggunakan awetan sehingga siswa lebih tertarik dan terlibat aktif dalam proses pembelajaran serta merupakan hal baru bagi siswa. Hal ini sesuai dengan pernyataan Suwono (2010) dalam Febriani et al., (2013) bahwa awetan memiliki kelebihan dapat memberikan pengalaman nyata dengan melakukan observasi secara langsung terhadap objek, menunjukan objek secara jelas dan menghindari verbalisme

Penggunaan awetan dalam kegiatan praktikum memberikan kesempatan siswa untuk menggunakan prosedur penelitian ilmiah dan metode penerapannya sehingga pembelajaran yang dilakukan oleh siswa lebih bermakna (Dikmenli, 2009 dalam Sobirin et al., 2013). Hal ini diperkuat oleh pernyataan Artasari et al., (2016) dan Anderson (1994) bahwa penggunaan media awetan dapat meningkatkan minat, keaktifan dan hasil belajar, memudahkan siswa dalam memahami materi yang disampaikan dan memberikan rangsangan keterampilan psikomotor. Kelebihan lain yang dimiliki oleh media awetan menurut Budiwati (2015) dalam Syafitri dan Hamidah (2016) adalah awetan dapat disimpan dalam waktu yang lama dan dapat digunakan berkali-kali sehingga mengurangi kerja guru dan meningkatkan efisiensi.

Penggunaan media awetan invertebrata dan panduan praktikum dalam kegiatan praktikum menurut Maknun et al., (2012) dalam Sobirin et al., (2013) berfungsi menghubungkan teori/konsep dan praktik, meningkatkan daya tarik atau minat siswa, memperbaiki miskonsepsi, dan mengembangkan sikap analisis dan kritis pada siswa. Hal ini diperkuat oleh Novitasari et al., (2013) yang menyatakan bahwa penggunaan media awetan dalam kegiatan praktikum yang disertai dengan LKS menunjukan keberhasilan pelaksanaan 
praktikum yang dibuktikan dengan siswa dapat menyelesaikan pengamatan tepat waktu, melaksanakan kegiatan sesuai prosedur dan sistematis, dan dapat meningkatkan ketuntasan hasil belajar.

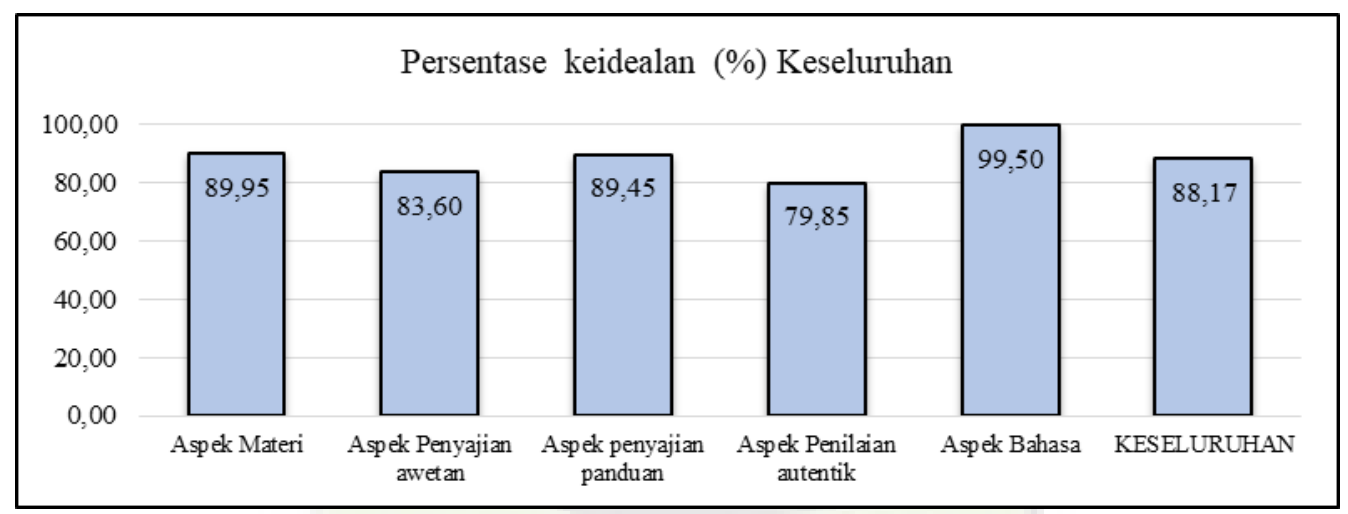

Gambar 5. Diagram persentase penilaian keseluruhan reviewer

Secara keseluruhan awetan dan panduan praktikum memperoleh nilai sebesar $88,17 \%$ (Lihat Gambar 5.) yang termasuk dalam kategori "sangat baik". Hal ini dikarenakan panduan praktikum telah memenuhi struktur bahan ajar cetak secara umum yang meliputi judul, petunjuk belajar, kompetensi dasar, atau materi pokok, tugas atau langkah kerja dan penilaian. Selain itu, bahan ajar cetak yang disusun juga telah memiliki tampilan yang jelas dan menarik, bahasa yang mudah, memiliki rangsangan yang mendorong pembaca untuk berpikir dan mudah dibaca (Prastowo, 2011).

\section{SIMPULAN}

Berdasarkan penelitian pengembangan yang telah dilakukan, dapat diperoleh beberapa simpulan. Pertama, keanekaragaman spesies Pantai Krakal termasuk dalam kategori sedang $\left(H^{\prime}=1,505\right)$. Jumlah spesies invertebrata yang ditemukan sebanyak 50 spesies yang terdiri dari 22 spesies Mollusca, 8 spesies Cnidaria, 7 spesies Echinodermata, 6 spesies Arthropoda, 4 spesies Porifera 2 spesies Annelida dan 1 spesies Platyhelminthes. Kedua, Media awetan dan panduan praktikum dikembangkan melalui 3 tahap yakni: pengambilan data dan gambar invertebrata, pengawetan invertebrata laut dan pengembangan panduan praktikum. Ketiga, Kualitas awetan dan panduan praktikum invertebrata menurut penilaian ahli materi, ahli media, peer reviewer, guru biologi dan siswa memiliki nilai persentase keidealan keseluruhan sebesar $88,17 \%$ yang termasuk kedalam kategori Sangat Baik (SB). 


\section{REFERENSI}

Adhayul, L.F, Purnomo. T., \& Ambarwati. 2014. Pengembangan Ensiklopedia dan LKS Invertebrata Laut untuk Pembelajaran Biologi. BioEdu Berkala Ilmiah Pendidikan Biologi. 3 (3): 580-588.

Anderson, R.H.,1987. Pemilihan dan Pengembangan Media untuk Pembelajaran. Jakarta: Rajawali.

Arifah, I., Arif, M., \& Siska, D.F. 2014. Pengembangan Buku Petunjuk Praktikum Berbasis Guided Inquiry untuk Mengoptimalkan Hands on Mahasiswa Semester II Program Studi Pendidikan Fisika Universitas Muhammadiyah Purworejo Tahun Akademik 2013/2014. Radiasi. 5(1): 24-28.

Artasari, Y., Lestari, R., Yolanda, R. 2016. Pengembangan Media Pembelajaran Spesimen Moluska pada Materi Animalia Kelas X di SMA Negeri 1 Rambah Samo. Riau: Program Studi Pendidikan Biologi Fakultas Keguruan dan Ilmu Pendidikan, Universitas Pasir Pengaraian. 1-7.

Cahyadi, W. 2009. Analisis dan Aspek Kesehatan Bahan Tambahan Pangan. Jakarta: Bumi aksara.

Dahuri, R. 2003. Keannekaragaman Hayati Laut. Jakarta: Gramedia Pustaka Utama.

Dibyowati, L. 2009. Keanekaragaman Moluska (Bivalvia dan Gastropoda). Di Sepanjang Pantai Carita, Pandegelan, Banten. Skripsi tidak diterbitkan. Bogor: Departemen Biologi. Fakultas Matematika dan Ilmu Pengetahuan Alam Insitut Pertanian Bogor.

Febriani, N., Yelianti, U., \& Gardjito, G., 2013. Pengembangan Media Pembelajaran Berupa Awetan Daun Untuk Mata Kuliah Struktur Tumbuhan pada Prodi Pendidikan Biologi. Prosiding Semirata. 159-163.

Fuji, M.S. 2014. Kurikulum 2013 dan Penilaian Diri. Tanggerang: Fakultas Ilmu Pendidikan. Universitas Pelita Harapan.

Hedianti, Rezki. 2015. Pengembangan Ensiklopedi Peralatan Biologi Sebagai Sumber Belajar IPA Biologi Untuk Siswa Kelas VII SMP/MTS. Skripsi. Skripsi tidak diterbitkan. Yogyakarta: Pendidikan Biologi Fakultas Sains dan Teknologi UIN Sunan Kalijaga Yogyakarta.

Imtihana, M.F., Putut M., \& Bambang P., 2014. Pengembangan Buklet berbasis Penelitian Sebagai Sumber Belajar materi Pencemaran Lingkungan di SMA. Journal of Biology Education. 3(2): 62-68.

Istianah, I., Widodo, J., \& Prasetya, E. 2012. Pengembangan Bahan Ajar dengan Pendekatan Metakognisi pada Materi Permintaan dan Penawaran Kelas X SMA Negeri 3 Demak. Journal of Educational Social Studies (JESS). 1(1): 31-36.

Khamidah, N. \& Aprilia, N. 2014. Evaluasi Program Pelaksanaan Praktikum Biologi Kelas XI SMA Se-Kecamatan Umbulharjo Yogyakarta Semester II Tahun Ajaran 2013/2014. Jupemasi-Pbio. 1: 5-8.

Khusnul, Laila. K., Pengembangan Modul Pembelajaran Materi Protista Berbasis Accelerates Learning dengan Pendekatan Saintifik untuk Kelas X SMA/MA. Skripsi tidak diterbitkan. Yogyakarta: Program Studi Pendidikan Biologi. Fakultas Sains dan Teknologi. Universitas Islam Negeri Sunan Kalijaga Yogyakarta.

Komalasari, K. 2011. Pembelajaran Kontekstual (Konsep dan Aplikasi). Bandung: PT Refika Aditama. 
Light, S.F., 1941. Laboratory and Field Text in Invertebrata Zoology. Berkeley: Associated Students Store University of California.

Mega, R.K., \& Soeparjitno, S. 2017. Pengembangan Media Video Pembelajaran Materi Pokok Invertebrata Mata Pelajaran Biologi untuk Meningkatkan Hasil Belajar Siswa Kelas X IPA di SMA Persatuan Tulangan Sidoarjo. Jurnal Mahasiswa Teknologi Pendidikan. 1 (3): 1-6.

Nikmah, R. \& Binadja, A. 2015. Pengembangan Diktat Praktikum Berbasis Guided Discovery-Inquiry Bervisi Science, Environment, Technology and Society. Jurnal Inovasi Pendidikan Kimia. 9 (1): 1506-1516.

Novitasari, L., Guntur, T., \& Yuni, S.R., 2016. Penggunaan Media Awetan pada Materi Jamur untuk Meningkatkan Ketuntasan Belajar Siswa Kelas X-1 SMA Negeri 1 Sekaran. Bioedu. 2(1): 6-9.

Pelczar, M. \& Chan, E.C.S. 2013. Dasar-dasar Mikrobiologi. Depok: UI Press.

Prastowo, A. 2011. Panduan Keratif Membuat Bahan Ajar Inovatif. Yogyakarta: Diva Press.

Rusyana, A. 2013. Zoologi Invertebrata (Teori dan Praktik). Bandung: Alfabeta.

Sobirin, M., Isnawati, I \& Ambarwati, R. 2013. Pengembangan Media Awetan Porifera untuk Pembelajaran Biologi Kelas X. BioEdu. 2 (1): 19-22.

Suhardi, S. 1988. Media Pendidikan Biologi Avertebrata. Jakarta: Departemen Pendidikan dan Kebudayaan Direktorat Jenderal Pendidikan Tinggi.

Suyitno, S. 2004. Penyiapan Spesimen Awetan Objek Biologi. Yogyakarta: FMIPA UNY.

Syafitri, R. dan Hamidah, A. 2016. Pengembangan Media Pembelajaran Koleksi Awetan Cangkang Gastropoda untuk Kelas X SMA (The Development of Media Learning Collection of Gastropods Shell Preserved for Class X in Senior High School). Biodik. 2(1): 34-42.

Trisna, A.W., Endah, S.I., \& Arief, M. 2016. Inventarisasi Jenis Dan Potensi Mollusca di Zona Pasang Surut Tipe Substrat Berbatu Pantai Gatra Kabupaten Malang. Seminar Nasional Pendidikan dan Saintek. 1-6.

Tuysuz, C., 2010. The Effect of the virtual laboratory on students' achievement and attitude in chemistry. IOJES. 2(1): 37-53.

Yanu, U.A. 2010. Molluska di Pesisir Barat Perairan Selat Lembah, Kota Bitung, Sulawesi Utara. Bumi Lestari. 10(1): 60-68. 